\title{
A Simple Preparation Route to Palladium Nanoparticles Catalyst from Decomposition of Supported $\left[\mathrm{Pd}(\mathrm{lysine} \cdot \mathrm{HCl})(\mathrm{Cl})_{2}\right]$ Complex
}

\author{
Yu-Zhi Hao*, Yu-Long Zhang, Li-Hua Wang and Xiao-Yan Ju \\ School of Chemical Engineering, Hebei University of Technology, Tianjin 300130, P.R. China
}

\begin{abstract}
The supported palladium nanoparticles catalyst with uniform-sized Pd particles distribution and without nitrogen or chlorine atoms present in catalyst was prepared by calcination of the supported $\left[\mathrm{Pd}(\right.$ lysine $\left.\cdot \mathrm{HCl})(\mathrm{Cl})_{2}\right]$ complex as precursor and characterized by TEM. Moreover the supported $\left[\mathrm{Pd}(\right.$ lysine $\left.\cdot \mathrm{HCl})(\mathrm{Cl})_{2}\right]$ complex was from cation exchanging $\left[\mathrm{Pd}(\right.$ lysine $\left.\cdot \mathrm{HCl})(\mathrm{Cl})_{2}\right]$ complex with inorganic support. The hydrogenation characteristic of supported Pd nanoparticles catalyst was evaluated by using benzoic acid.
\end{abstract}

Keywords: Nanostructure, heat treatment, electron microscopy, microstructure.

\section{INTRODUCTION}

Catalytic hydrogenation is one of the key processes in fine chemicals production. Palladium is a very important metal catalyst in the field of organic and inorganic synthesis for the past three decades [1]. Palladium metal with nanometer-scale dimension is of particular interest due to its catalytic ability, thus the synthesis technology of Pd nanoparticles with uniform-size is very important and attractive in the research area. Several literature reports are related to the development of supported metal nanoparticles on solid supports. These reports include adsorption/impregnation [2-10], immobilization on surfaces functionalized with appropriate ligands [11-13], coprecipitation [2,14], sol-gel [2,15], vaporphase deposition of organometallic complexes [16], microemulsion [17], diffusion of preformed nanoparticles into the pores via sonication [18], and fabrication of nanoparticles via electron beam lithography [19,20]. In $\mathrm{PdCl}_{2}$ or $\left[\mathrm{Pd}\left(\mathrm{NH}_{3}\right)\right.$ $\left.{ }_{4}\right]^{2+}$ adsorption/impregnation method, the reduction in a relatively low temperature must be carried out by chemical reducer after adsorption/impregnation, i.e. hydrazine, alcohol, $\mathrm{NaBH}_{4}$ etc. Because of the adsorption action of support or metal Pd, the nitrogen or chlorine atoms produced during preparation will remain in catalyst, which will make the catalytic activity of bifunctional catalyst decrease $[9,10]$. N. Nishimiya [21] et al. synthesized Pd nanoparticles by high temperature calcination and reduction technology. The main results were that the nitrogen or chlorine atoms were taken out from the catalyst and the Pd nanoparticles size was only $10-15 \mathrm{~nm}$.

Generally, the cost of ligand in the organometallic complex is high. In the present work, the supported Pd nanoparticles catalysts with uniform-sized Pd particles distribution and without nitrogen or chlorine atoms present in catalysts were directly prepared by means of calcination of supported palladium complex. The ligand of the palladium complex was a lysine salt which is easily decomposed at a relatively

\footnotetext{
*Address correspondence to this author at the School of Chemical Engineering, Hebei University of Technology, Tianjin, 300130, P.R.China; Tel: +8622-60200435; Fax: +86-22-60204294; E-mail: hyzhsong@sina.com
}

low temperature and contains a free $-\mathrm{NH}_{3}{ }^{+}$cation. The free $\mathrm{NH}_{3}{ }^{+}$cation can exchange with inorganic support and can be immobilized on the support. The supported Pd nanoparticles catalyst prepared was characterized by TEM. Hydrogenation activities were evaluated by using benzoic acid to give cyclohexane carboxylic acid.

\section{EXPERIMENTAL}

\subsection{Materials}

All the chemicals were obtained from Tianjin Reagent Company in P. R. China and used as such without further purification. Zeolite $\mathrm{NaY}$ with $\mathrm{S}_{\mathrm{BET}}=766 \mathrm{~m}^{2} / \mathrm{g}$, and $\mathrm{Si} / \mathrm{Al}=2.86$ was from Wenzhou Catalyst Factory in P. R. China. The commercially available Pd metal was obtained from Chinese Jinchuan Colored Metal Company.

\subsection{Preparation of Palladium Complex $\left[\mathrm{Pd}(\mathrm{lysine} \cdot \mathrm{HCl})(\mathrm{Cl})_{2}\right][22]$}

$\mathrm{H}_{2} \mathrm{PdCl}_{4}$ solution was prepared by adding $2.1093 \mathrm{~g}$ commercial palladium metal $(99.99 \%)$ and $20 \mathrm{~mL} \mathrm{HCl} \mathrm{(33 \% )} \mathrm{in}$ $100 \mathrm{~mL}$ three-necked flask with cooling water bath at room temperature, slow dropping $10 \mathrm{~mL} \mathrm{H}_{2} \mathrm{O}_{2}$ solution (30\%) under vigorous stirring, and controlling the mixture temperature below $30^{\circ} \mathrm{C}$ until all palladium metal was dissolved. Finally, the solution was diluted to $100 \mathrm{~mL}$.

The preparation of $\left[\mathrm{Pd}(\right.$ lysine $\left.\cdot \mathrm{HCl})(\mathrm{Cl})_{2}\right]$ complex was shown as follows: $10.0 \mathrm{~mL}$ the $\mathrm{H}_{2} \mathrm{PdCl}_{4}(\mathrm{Pd} 21.09 \mathrm{mg} / \mathrm{mL})$ solution prepared above was diluted to $30 \mathrm{~mL}$ in a $100 \mathrm{~mL}$ three-necked flask. Several drops of $0.1 \mathrm{M} \mathrm{NaOH}$ solution was added until reaching $\mathrm{pH} \sim 4-5$. The lysine $\cdot \mathrm{HCl}$ which was $0.3661 \mathrm{~g}(1.989 \mathrm{mmol})$ was introduced into the prepared solution, and the mixture was stirred vigorously at $60-70{ }^{\circ} \mathrm{C}$ for $2 \mathrm{~h}$.

\subsection{Supported $\left[\mathrm{Pd}(\mathrm{lysine} \cdot \mathrm{HCl})(\mathrm{Cl})_{2}\right]$ Complex}

In a typical synthesis, $2.0 \mathrm{~g} \mathrm{NaY}, 120 \mathrm{~mL}$ deionised water were added into $250 \mathrm{~mL}$ three-necked flask, the mixture was stirred vigorously and heated to $60{ }^{\circ} \mathrm{C}$ in water bath for $1 \mathrm{~h}$. Several drops of $0.1 \mathrm{M} \mathrm{HCl}$ solution was added until reaching $\mathrm{pH} \sim 5 .\left[\mathrm{Pd}(\right.$ lysine $\left.\cdot \mathrm{HCl})(\mathrm{Cl})_{2}\right]$ complex $(13 \mathrm{~mL})$ 
prepared above was introduced into the mixture, and the mixture was maintained at $60{ }^{\circ} \mathrm{C}$ under vigorous stirring for $4 \mathrm{~h}$. The mixture was cooled to room temperature. Finally, the solid was filtered, and washed with deionised water until $\mathrm{Cl}^{-}$was not determined. Then, it was dried at $80{ }^{\circ} \mathrm{C}$ for $10 \mathrm{~h}$, and grinded to $80 \mu \mathrm{m}$. It was noted as PdL-NaY.

\subsection{Preparation of Palladium Nanoparticles Catalyst}

The PdL-NaY product was placed in muffle furnace and slowly heated up to $120{ }^{\circ} \mathrm{C}$ for $24 \mathrm{~h}, 300{ }^{\circ} \mathrm{C}$ for $2 \mathrm{~h}$ and $500{ }^{\circ} \mathrm{C}$ for $2 \mathrm{~h}$ in air (temperature ramp: $5^{\circ} \mathrm{C} / \mathrm{min}$ ), respectively. $2.0 \mathrm{~g}$ products prepared above were maintained at 60 ${ }^{\circ} \mathrm{C}$ under stirring for $2 \mathrm{~h}$ in $100 \mathrm{~mL} 2 \% \mathrm{NaCl}$ solution. The mixtures were cooled to room temperature. The solids were filtered, and washed with deionised water until $\mathrm{Cl}^{-}$was not determined. The products were dried at $120^{\circ} \mathrm{C}$ in oven for 2 $\mathrm{h}$, and were not reduced in $\mathrm{H}_{2}$ before hydrogenation reaction. They were noted as Nano-1, Nano-2, Nano-3, respectively.

\subsection{Catalytic Test Reaction}

The liquid-phase hydrogenation of reactant benzoic acid (99\% purity) was investigated in a $1 \mathrm{~L}$ stainless autoclave equipped with a pressure regulator, which ensured that the reactions proceeded at a constant hydrogen pressure. The mass of catalyst was $4 \mathrm{~g}$. The mass of reactant benzoic acid was $100 \mathrm{~g}$, and the solvent ethanol was $80 \mathrm{~mL}$. The mixture was pressed and vented three times with $\mathrm{N}_{2}$ and $\mathrm{H}_{2}$ respectively, and the pressure was set to 1.0-1.4 Mpa. The reaction commenced by starting the stirring, and the autoclave was heated to $120-140{ }^{\circ} \mathrm{C}$ (temperature ramp $5{ }^{\circ} \mathrm{C} / \mathrm{min}$ ). After
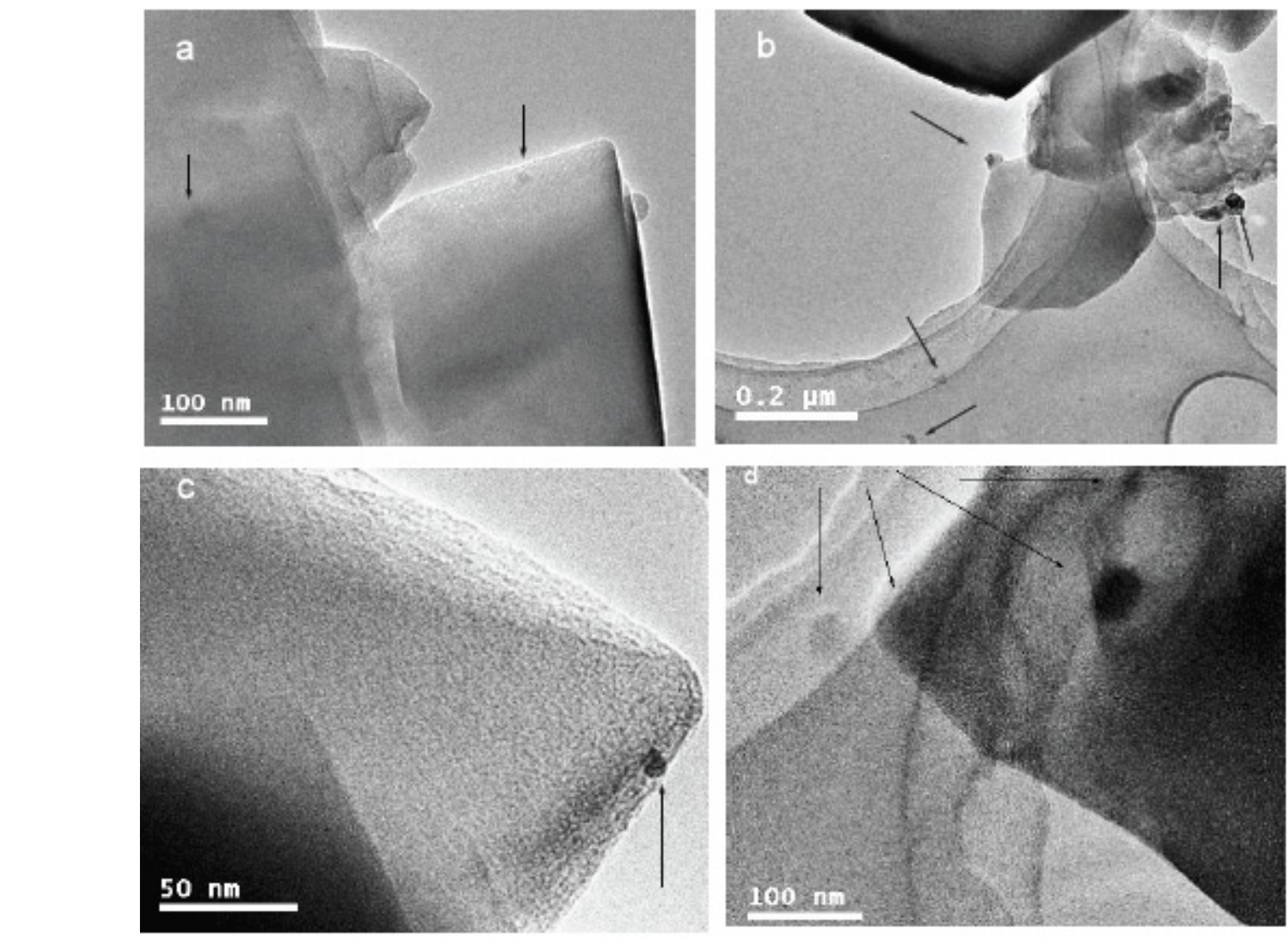

reaction for $4 \mathrm{~h}$, the autoclave was cooled to room temperature, and was depressurized and replaced three times by $\mathrm{N}_{2}$. The catalyst was filtered, and the organic phase was analyzed with Shimadzu 9A gas chromatography which was equipped with a polyglycol capillary column $(30 \mathrm{~m})$ and a flame ionization detector (FID). The catalytic activities were characterized by reaction conversion and the cyclohexane carboxylic acid selectivity.

\subsection{Sample Characterization}

The Pd contents of the samples were determined by inductively coupled plasma (ICP) atomic emission spectrometry. TEM images were recorded with a Tecnai $\mathrm{G}^{2} 20 \mathrm{~S}-\mathrm{T}$ WIN transmission electron microscope. The samples suspended in ethanol were mounted on carbon-coated copper grids and then the solvent was evaporated.

\section{RESULTS AND DISCUSSION}

\subsection{Supported $\left[\mathrm{Pd}(\mathrm{lysine} \cdot \mathrm{HCl})(\mathrm{Cl})_{2}\right]$ Complex}

Our former work [22] has shown that $\mathrm{N}$ (from $\alpha-\mathrm{NH}_{2}$ group) and $\mathrm{O}$ (from $-\mathrm{OH}$ group in $-\mathrm{COOH}$ ) atoms in lysine $\mathrm{HCl}$ can form coordination bonds with $\mathrm{Pd}$ atom from $\mathrm{H}_{2} \mathrm{PdCl}_{4}$ solution, which constitutes the five-membered chelating ring complex. There is a free $-\mathrm{NH}_{3}{ }^{+}$cation remained in $\left[\mathrm{Pd}(\right.$ lysine $\left.\cdot \mathrm{HCl})(\mathrm{Cl})_{2}\right]$ complex. Therefore, the $\left[\mathrm{Pd}(\right.$ lysine $\left.\cdot \mathrm{HCl})(\mathrm{Cl})_{2}\right]$ complex can exchange with the other cations in support, e.g. $\mathrm{Na}^{+}, \mathrm{NH}_{4}^{+}, \mathrm{Ca}^{2+}$ etc., and may be supported in the inorganic support by way of the interaction of ionic bonds [23]. In present research work, the $\left[\mathrm{Pd}(\right.$ lysine $\left.\cdot \mathrm{HCl})(\mathrm{Cl})_{2}\right]$ complex exchanged with $\mathrm{Na}^{+}$in $\mathrm{NaY}$,

Fig. (1). The TEM images of Nano-1 catalyst. 
and was immobilized in $\mathrm{NaY}$. Its scheme was as follows (Scheme 1).
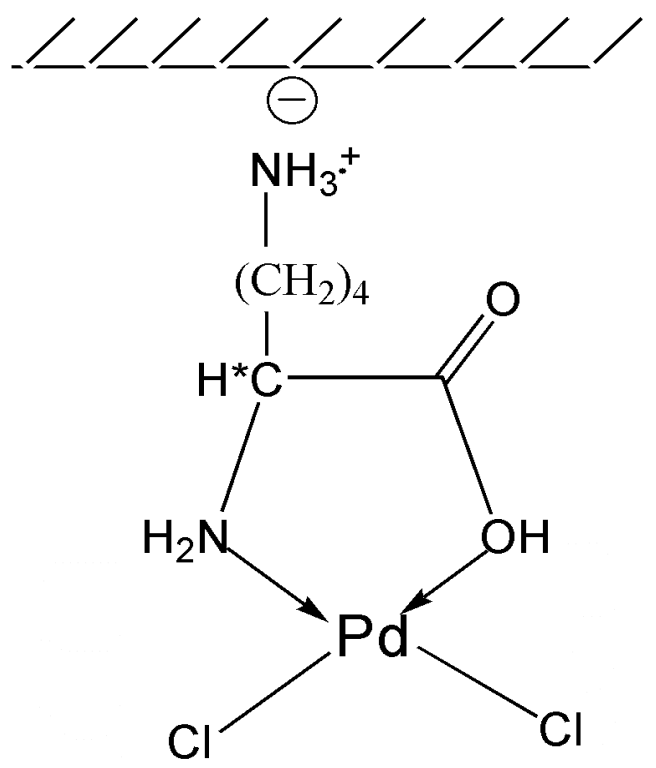

Scheme 1.

\subsection{Characteristic of Palladium Nanoparticles Catalyst}

Figs. (1-3) are the TEM images of Nano-1 2 samples prepared at different calcination conditions. It is found that when Nano- 1 was calcinated at $120{ }^{\circ} \mathrm{C}$ for $24 \mathrm{~h}$, the palladium particle sizes of Nano-1 (Fig. 1) distribute broadly, where a few Pd particles appeared in every image. But some small Pd particles can be clearly observed. The smaller particle size is within $10 \mathrm{~nm}$, and the larger one is about $40-50$ nm. The Nano-2 (Fig. 2) sample shows the occurrence of high dispersed uniform-sized Pd nanoparticles, which are mainly distributed between $5 \mathrm{~nm}$ and $10 \mathrm{~nm}$. There are many $\mathrm{Pd}$ particles appearance in each image. However, the palladium particle sizes of Nano-3 (Fig. 3) distribute broadly. The smallest particle size is about $20 \mathrm{~nm}$, and the largest one is about 60-70 nm. These results show that the $\left[\mathrm{Pd}(\right.$ lysine $\left.\cdot \mathrm{HCl})(\mathrm{Cl})_{2}\right]$ complex may be not completely decomposed at $120{ }^{\circ} \mathrm{C}$ for $24 \mathrm{~h}$. It seems too long decomposing time, in which the $\mathrm{Pd}$ particles produced get together and become larger. It seems too high for the decomposition temperature at $500{ }^{\circ} \mathrm{C}$, because the $\mathrm{Pd}$ particles can assemble to become more larger particles at $500{ }^{\circ} \mathrm{C}$. This further verifies that calcination temperature is very important, and delaying calcination time at a definite calcination temperature is disadvantage. Therefore, the better calcination condition should be at $300{ }^{\circ} \mathrm{C}$ for $2 \mathrm{~h}$ for supported $\left[\mathrm{Pd}(\right.$ lysine $\left.\cdot \mathrm{HCl})(\mathrm{Cl})_{2}\right]$ complex.

A representative local elemental analysis of Nano-2 sample was presented in Fig. (4). Nano-2 catalyst included the atoms of palladium, silicon, aluminum, sodium, oxygen and carbon atoms, and did not include any other kinds of atoms, including nitrogen and chlorine atoms. This verifies that the nitrogen or chlorine atoms are not presented in the catalyst. The silicon, aluminum, sodium and oxygen atoms may come from inorganic support $(\mathrm{NaY})$, and a few carbon atoms may come from remainder of decomposed lysine. Therefore, $\mathrm{Pd}$ nanoparticles catalyst with uniform-sized Pd particles distribution and without ammonium or chlorine atoms in catalyst can be prepared by calcination of the supported $\left[\mathrm{Pd}(\right.$ lysine $\left.\cdot \mathrm{HCl})(\mathrm{Cl})_{2}\right]$ complex as precursor.

Otherwise, according to Figs. (1-3), when the Pd particle size is within $10 \mathrm{~nm}$, the morphology of $\mathrm{Pd}$ nanoparticles is more or less hemispherical, and the Pd nanoparticles contact with the support closely. When the Pd particle size is above $20 \mathrm{~nm}$, the morphology of Pd nanoparticles is not uniform, and the Pd nanoparticles locate on the outside surface of the support.

\subsection{Catalytic Test Reaction}

The hydrogenation activities and Pd contents of palladium nanoparticles catalysts were summarized in Table $\mathbf{1}$ The Pd contents were from 4.0 to $4.7 \mathrm{wt} \%$ in these catalysts. . Benzoic acid could be hydrogenated to cyclohexane carboxylic acid at $130{ }^{\circ} \mathrm{C}$ by palladium nanoparticles catalysts prepared above, and the hydrogenation selectivity was better. There were different hydrogenation activities on different catalysts. The hydrogenation activity of Nano-2 sample calcined at $300{ }^{\circ} \mathrm{C}$ was the best. Comparing with Nano-2, the Nano-3 sample which is much larger Pd particle size, as well as the Nano-1 with a broad particle size and a few metal particles, showed poorer performance. In this case, the decrease
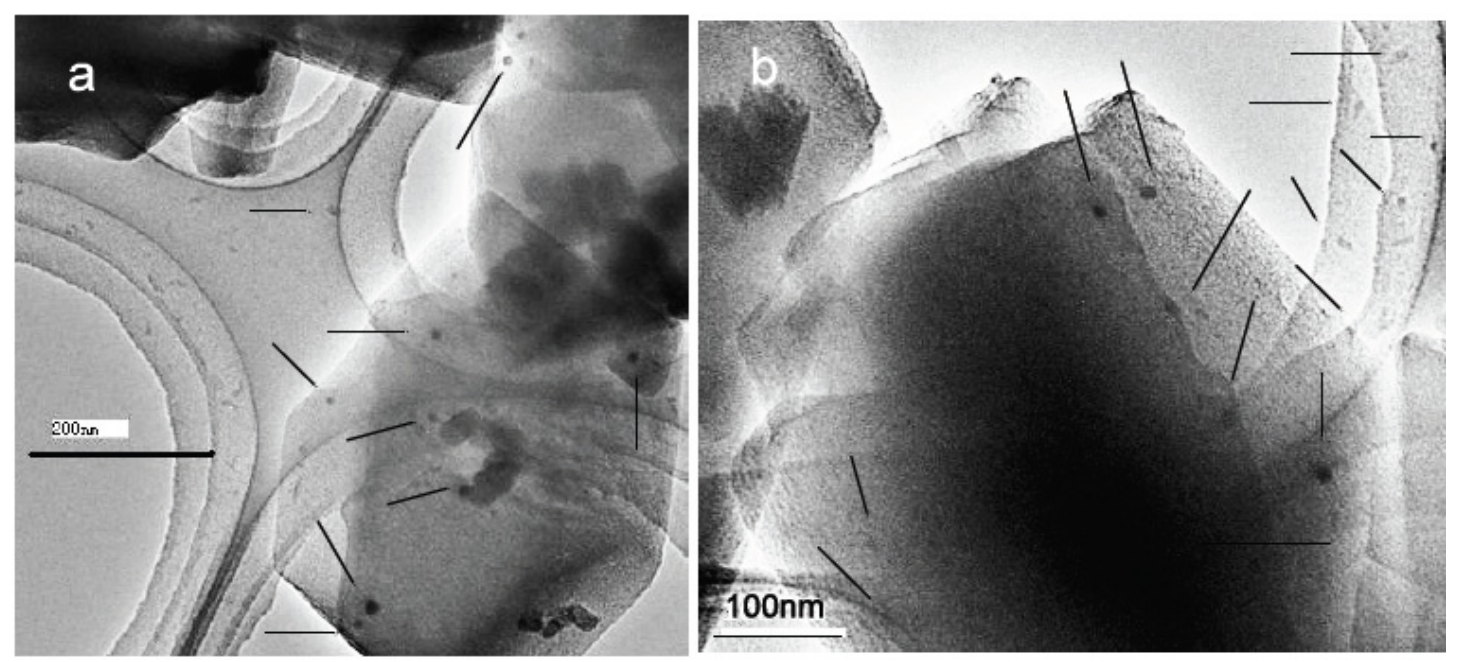

Fig. (2). The TEM images of Nano-2 catalyst. 

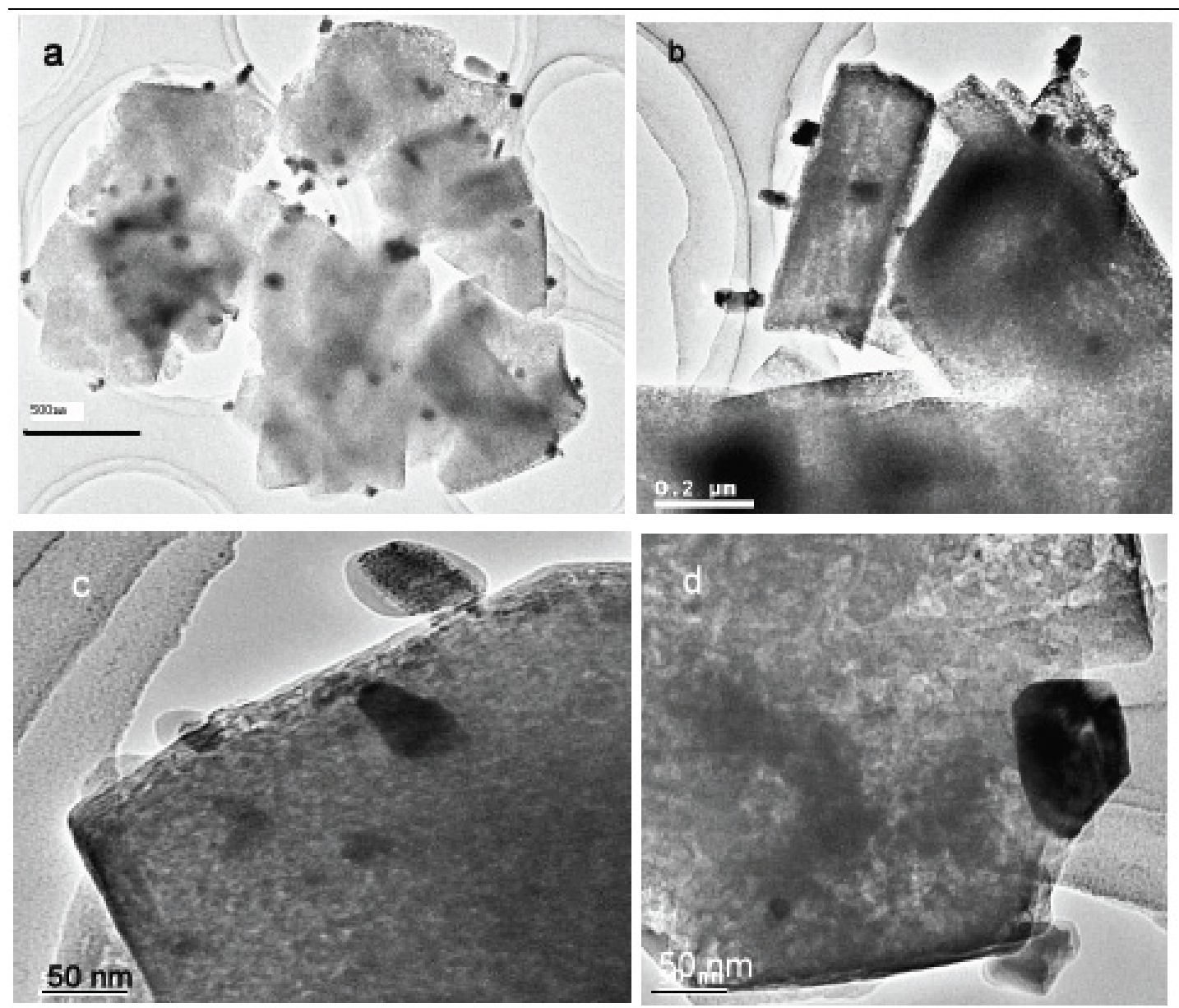

Fig. (3). The TEM images of Nano-3 catalyst.

0

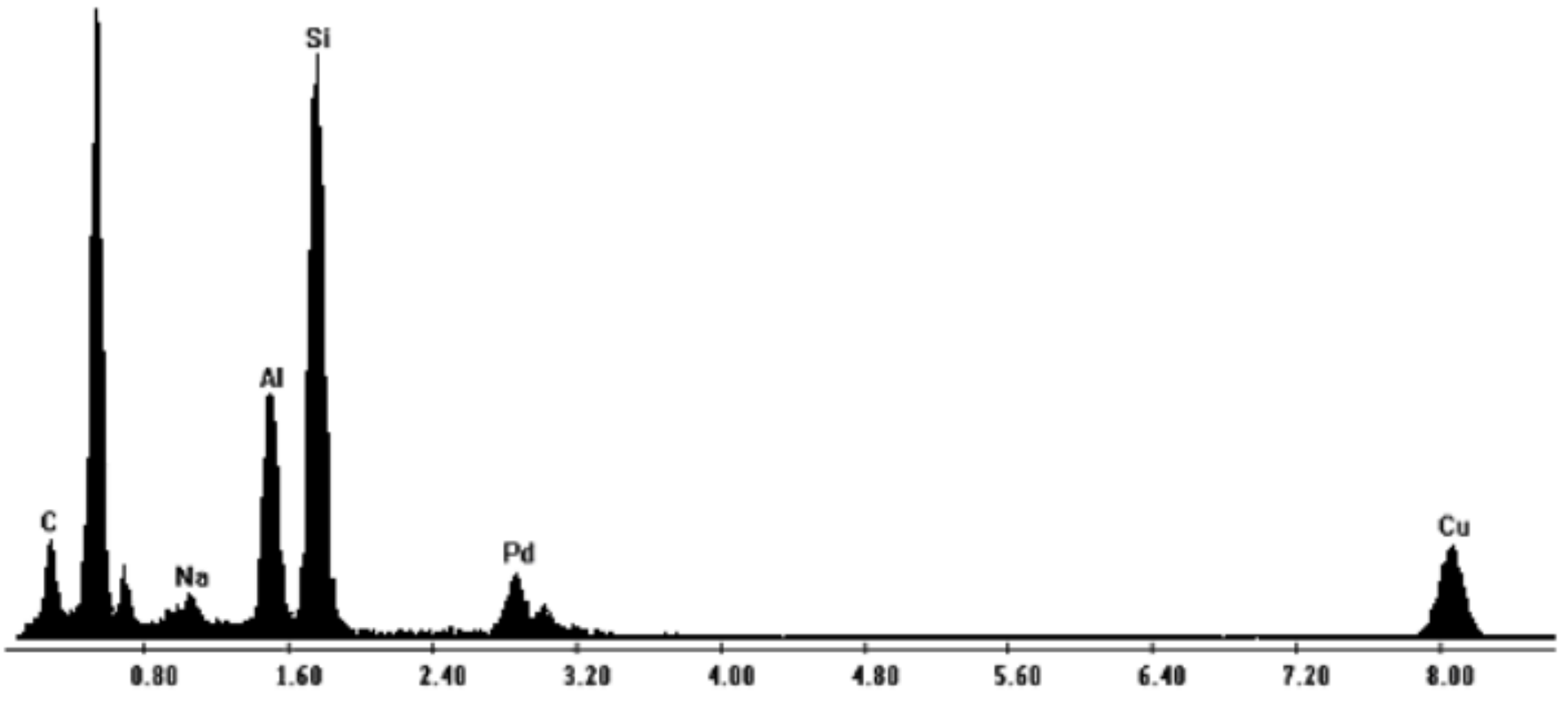

Fig. (4). The TEM local elemental analysis of Nano-2 catalyst.

in the catalytic performance is expected because of the increase in the Pd particle size or the decrease of the amount of the Pd metal particles. The hydrogenation conversion of
Nano-2 catalyst was above $89 \%$, and the selectivity of cyclohexane carboxylic acid was above $96 \%$ at $130{ }^{\circ} \mathrm{C}$ and 1.2 Mpa. 
Table 1. The Pd Contents and Catalytic Activities of Nano-1, Nano-2 and Nano-3 Catalysts for the Hydrogenation of Benzoic Acid

\begin{tabular}{|l|c|c|c|c|c|}
\hline Catalyst & $\begin{array}{c}\text { Pd } \\
\text { Contents } \\
(\mathbf{w t . \% )}\end{array}$ & $\begin{array}{c}\mathbf{T} \\
\left({ }^{\circ} \mathbf{C}\right)\end{array}$ & $\begin{array}{c}\mathbf{H}_{2} \text { Press. } \\
(\mathbf{M p a})\end{array}$ & $\begin{array}{c}\text { Reaction } \\
\mathbf{C o n v} . \\
\mathbf{( \% )}\end{array}$ & $\begin{array}{c}\text { Reaction } \\
\text { Select. } \\
\mathbf{( \% )}\end{array}$ \\
\hline \hline Nano-1 & 4.0 & 130 & 1.2 & 68.8 & 86.9 \\
\hline Nano-2 & 4.5 & 130 & 1.2 & 89.1 & 96.5 \\
\hline Nano-3 & 4.7 & 130 & 1.2 & 55.3 & 84.2 \\
\hline
\end{tabular}

\section{CONCLUSION}

The catalysts consisting of nanometer-sized Pd particles are synthesized by way of a simple technique. No nitrogen or chlorine atoms are present in the catalysts. These catalysts were tested for the hydrogenation of benzoic acid in ethanol under hydrogen pressure. Catalyst calcined at $300{ }^{\circ} \mathrm{C}$ for $2 \mathrm{~h}$ gave the best activity. The $\mathrm{Pd}$ particle size seems to play an important role in increasing the activity in the hydrogenation reaction.

\section{REFERENCE}

[1] Malleron, J. L.; Fiaud, J. C.; Legros. J. Y.; Eds., Handbook of Palladium-Catalysed Organic Reaction, Academic Press: London, 1997.

[2] Mu, X. D.; Evans, D. G.; Kou, Y. A general method for preparation of PVP-stabilized noble metal nanoparticles in room temperature ionic liquids. Catal. Lett., 2004, 97, 151-4.

[3] Yoo, J. W.; Hathcock, D. J.; El-Sayed, M. A. Propene hydrogenation over truncated octahedral Pt nanoparticles supported on alumina. J. Catal., 2003, 214, 1-7.

[4] Yoo, J. W.; Hathcock, D. J.; El-Sayed, M. A. Characterization of pt nanoparticles encapsulated in $\mathrm{AlO}$ and their catalytic efficiency in propene hydr ogenation. J. Phys. Chem. A, 2002, 106, 2049-54.

[5] Lang, H.; May, R. A.; Eversen, B. L.; Chandler, B. D. Dendrímorertcapeulatod nanoparticle precursors to supported platinum catalysts. J. Am. Chem. Soc., 2003, 125, 14832-36.

[6] Han, Y. J.; Kim, J. M.; Stucky, G. D. Preparation of noble metal nanowires using hexagonal mesoporous silica SBA-15. Chem. Mater., 2000, 12, 2068-69.

[7] Kaluza, S.; Schröter, M. K.; D’Alnoncourt, R.N,; Reinecke. T. Muhler M. High Surface Area ZnO Nanoparticles via a Novel Continuous Precipitation Route. Adv. Funct. Mater., 2008, 18, 3670-7.

[8] Meric, P.; Yu, K. M.; Kong, A.T.S.; Tsang, S. C. Distribution of citral hydrogenation over micelle-hosted $\mathrm{Pd}$ and Ru nanoparticles in supercritical carbon dioxide. J. Catal., 2006, 237, 330-6.
[9] Semagina, N.; Renken, A.; Laub, D.; Kiwi-Minsker, L. Synthesis of monodispersed palladium nanoparticles to study structure sensitivity of solvent-free selective hydrogenation of 2-methyl-3-butyn2-ol. J. Catal., 2007, 246, 308-14.

[10] Chen, L. J.; Wan, C. C.; Wang, Y. Y. Chemical preparation of Pd nanoparticles in copper deposition. J. Colloid Interface Sci., 2006, 297, 143-50.

[11] Müller, M.; Zhang, X.; Wang, Y.; Fischer R. A. Nanometer-sized titania hosted inside MOF-5. Chem. Commun., 2009, 119-121.

[12] Chen, C. W.; Serizawa, T.; Akashi, M. Preparation of platinum colloids on polystyrene nanospheres in hydrogenation. Chem. Mater., 1999, 11, 1381-9.

[13] Narkhede, V.; Gies, H. Deposition and characterization of functional nanoparticles of lead-zirocnia titanate (PZT) in materices of mesoporous silica of MGM-48-type structure. Nanoporous Mater. Singapore, 2008, 55-62.

[14] Claus, P.; Bruckner, A.; Mohr, C.; Hofmeister, H. Supported gold nanoparticles from quantum dot to mesoscopic size scale: effect of electronic and structural properties on catalytic hydrogenation of conjugated functional groups. J. Am. Chem. Soc., 2000, 122, 11430-9.

[15] Martino, A.; Yamanaka, S. A.; Kawola, J. S.; Loy, D.A. Encapsulation of gold nanoclusters in silica materials via an inverse micelle/Sol-Gel synthesis. Chem. Mater., 1997, 9, 423-9.

[16] Paulus, U. A.; Endruschat, U.; Feldmeyer, G. J.; Schmidt, T. J.; Bonnemann, H.; Behm, J. J. New PtRu alloy colloids as precursors for fuel cell catalysts. J. Catal., 2000, 195, 383-93.

[17] Papp, S.; Dekany, I. Structural properties of palladium nanoparticles embedded in inverse microemulsions. Colloid Polym. Sci, 2001, 279, 449-58.

[18] Rioux, R. M.; Song, H.; Hoefelmeyer, J. D.; Yang, P.; Somorjai, G. A. High-surface-area catalyst design: synthesis, characterization, and reaction studies of platinum nanoparticles in mesoporous SBA15 silica. J. Phys. Chem. B, 2005, 109, 2192-02.

[19] Eppler, A.; Rupprechter, G.; Guczi, L.; Somorjai, G. A. Model catalysts fabricated using electron beam lithography and pulsed laser deposition. J. Phys. Chem. B, 1997, 101, 9973-77.

[20] Eppler, A.S.; Rupprechter, E.A.; Anderson, E. A.; Somorjai, G. A.; The thermal and chemical stability and adhesion strength of $\mathrm{pt}$ nanoparticle arrays supported on silica studied by TEM and AFM. J. Phys. Chem. B, 2000, 104, 7286-92.

[21] Nishimiya, N.; Kishi, T.; Mizushima, T.; Matsumoto, A.; Tsutsumi, K. Hyperstoichiometric hydrogen occlusion by palladium nanoparticles included in NaY zeolite. J. Alloys Compd., 2001, 319, 31221.

[22] Hao, Y. Z..; Li, Z. X.; Tian, J. L. Synthesis.characteristic and catalytic activity of water-soluble [Pd(lysine. $\mathrm{HCl})(\mathrm{Cl}) 2]$ complex as hydrogenation catalyst. J. Mol. Catal. A Chem., 2007, 265, 258-67.

[23] Chen, B.; Dingerdissen, U.; Krauter, J. G.; Lansink E.; Rotgerink, H. G. J.; Mobus, K.; Ostgrd, D.J.; Panster, P.; Riermeier, T. H.; Seebald, S.; Tacke, T.; Trauthwein, H. New developments in hydrogenation catalysis particularly in synthesis of fine and intermediate chemicals. Appl. Catal. A, 2005, 280, 17-46. 